\title{
Al-Ghazali, Dialogic Practices in Islam and Religious Education in a Saudi University
}

\author{
Adel Abubaker Bawazeer \\ University of Jeddah, Saudi Arabia
}

\begin{abstract}
Improving religious education is considered a key driver in enabling Saudi society to become more open to different points of view, especially through the practice of dialogue. Additionally, universities might be seen as being in the best place to enable them to carry out their responsibilities to educate the public by engaging them in rational dialogic practices. The project reported in this paper, closely examined the features of religious education with particular focus on a model within the on-going Islamic tradition that might be drawn upon in relation to such dialogic practice. Al-Ghazali is an exemplar of dialogic practice within the Islamic tradition whose work testifies to the possibility of combining a tradition-centered approach with more open dialogic practice. In his case, such openness to difference was combined with both a respect for the Qu'ran and Sunna, and other Islamic foundational texts, and the practice of his tradition. Based on that, the paper looks at ways of encouraging students to present their opinions and the requirement for academic teachers to be more open to help them to be successful in stimulating their students to engage in dialogue without fear of disagreement. The paper examines how this dialogic activity in religious education might be framed by the thought of AlGhazali as a model and the Islamic tradition within university classes.
\end{abstract}

\section{Introduction}

In recent times, $\mathrm{Al}$ Ghazali has been considered one of the most popular thinkers among Muslim Sunni scholars. The importance of his vision is that he instituted a new school of Islamic thought that concentrated on the practices of Islamic theory. For the past nine centuries, Al-Ghazali's ideas have influenced Islamic intellectual output because they combine Islamic law (Shari'a), history, and education.

Al-Ghazali began seeking knowledge in early childhood, becoming a teacher who moved between various large and small schools until he was called to be a professor in the university in Baghdad. Until the end of the eleventh century he dedicated his life to teaching and educating. Despite reaching this position, al-Ghazali underwent a "spiritual crisis" in that period [12], which had a significant impact on his subsequent thought and life. Some of the intellectual conflicts he underwent appeared subsequently in his writings. One of the most famous of these works is Tahäfut al-Faläsifah (The Incoherence of the Philosophers). Written in the late 11 th century, this book addressed and challenged all the contradictions he identified in the thoughts of philosophers of the time, including Ibn Sina (Avicenna) and Al-Farabi (Alpharabius) regarding God (Allah) and the universe, as well as faith and theology [12], [13].

At the beginning of the 12th century Al-Ghazali suddenly decided to abandon teaching. He found himself unable to give speeches: "God shrivelled my tongue until I was prevented from giving instruction. So, I used to force myself to teach on a particular day for the benefit of my various pupils, but my tongue would not utter a single word" [7]. Instead, he set out to discover what was beyond the knowledge which had initially led him to the stage of certainty, in search of spiritual stability [12].

Although Al-Ghazali relinquished his position in teaching, he did not leave the field of education but instead began a life of contemplation and writing. In this phase of isolation, the first text he wrote was to become famous. Ihya' ' 'Ulüm Al-dīn (The Revival of the Religious Sciences) was a product of his long years spent in teaching [12], paying attention to issues of education, ethics, mysticism, jurisprudence and faith, supporting "the very materials used by his predecessors, such as verses of the Qur'an; prophetic reports (AHadith); philosophical, legal, and theological discourses; and the narratives of mystics." [14]. This book holds a great appeal to a large segment of Muslims [12], but has also faced a variety of criticisms, mainly directed at the mystical element which is prominent in this book [1].

At the end of this period of isolation, al-Ghazali wrote "al-Munqidh min al-Dalal" (Deliverance from Error), which reflects the maturity and spiritual stability that he had achieved. The primary motivation for al-Ghazali in writing this book, as stated in its introduction, is to show the correct path to God (Allah), based on the intellectual and spiritual conflicts he had faced. Indeed, the main question for al-Ghazali was how to avoid doubt right up to the final choices of truth, certainty, and final ratification [12], [13]. He concluded that the correct path did not reside in theology, nor in philosophy, neither in 
educational doctrine; rather, the solution to his existential and intellectual quandaries was to cease searching for solutions that could be reached intellectually, but to seek solutions by actually "tasting" what God is like through mystical experience. In this abandonment of the purely mental struggle of what can be grasped by the mind in favour of the fuller experience of truth that can be absorbed by the whole person, lies the crux of alGhazali's life, and, in many important respects, the crux of Islam [12].

The two books discussed above are considered as al-Ghazali's most important works, because they relate to the different intellectual and spiritual stages of his life, reflecting his journey from spiritual conflict to isolation and finally to mysticism and spiritual stability, prompting scholars to call alGhazali "an enigmatic and agonistic figure" [14]. Nonetheless, he left a non-totalitarian legacy of knowledge and intellect, which some see as representing a key intellectual and scientific leap in the Islamic intellectual tradition [14]. Therefore, there are powerful reasons for engaging with his thinking in relation to traditions of thinking and the encounter with heterogeneous knowledge traditions.

With regard to the ambiguity of al-Ghazali's thought, Moosa [14], in reviewing Ibn Rushd's opinion of al-Ghazali, discusses as an example a famous debate between the two thinkers. After the debate, al-Ghazali described the discussions that he had with Ibn Rushd as constructive, while Ibn Rushd described them as offensive [14]. Ibn Rushd's main criticism of al-Ghazali was that he was a man of many parts who was non-traditional in his thought and was diverse and volatile "who pretended to be an Ashari when he was with theologians of that stripe, a mystic with the súfis, and a philosopher with philosophers" [14].

Al-Ghazali did not see intellect and thought as limited or restricted, and that is what made him such a prolific generator of ideas that have opened up the consideration of multiple concepts throughout the centuries into the modern era [14]. The openness of al-Ghazali's thinking was bounded by the principal sources (Qur'an and Sunnah); however, other philosophers believe that there is no boundary at all [12], [13]. So, what is the difference here? What was al-Ghazali doing? Within that boundary of a tradition of thinking, al-Ghazali used the method of opening enquiries and questions "and sought to provide answers to his dilemmas and challenges as to what kind of Muslim subjectivity was required in order to create a new knowledge for his time" [14]. What we can say is that the difference was that his approach opened the spaces of debate, resulting in a 'critical tension brought about by dialogical thinking' [14].

The previous discussion raises a question about al-Ghazali's thought: what resources does this particular thinker offer? According to Moosa [14], he "was a frontier thinker" offering unique concepts that opened up the possibility of diversity of thought and multiple narratives: "dihlīz", as an interspace [14]. Dihlīz a Persian word Arabized and meaning "that space between the door and the house"' [14]. In "alMunqidh min al-Dalal" (Deliverance from Error) alGhazali uses this word in a phrase very well-known among Muslim scholars, which is: "And whatever precedes it is like a threshold for the seeker of God [Wa mā qabla dhālika ka al-dihlīz li al-sālik ilayhi]" [14]. Used in the context of explaining the relationship between the Muslim mystic and his God $($ Allah), it is also used to explain that there are a variety of ways of meeting in a single space in order to reach to God (Allah). It is also used in other ways, as a 'spatial metaphor [that] signifies a multitude of meanings' [14]. So, what are these indications and metaphors and how might the concept of "dihlīz" be a useful concept in thinking about dialogue?

Moosa [14] provides an in-depth interpretation of the word "dihlizz" showing its relevance to alGhazali's thought in general and dialogical thinking in particular. Firstly, he explains that this concept could be considered as a reflection of al-Ghazali's thought, in the sense that intellectual dialogues must combine both fundamentals and constants. In this description, using a geographical metaphor, Moosa likens al-Ghazali's mind to one that lies on the borders "between sovereign territories and criminalizes improper crossing without authorization. But it also compels one to choose. A person invariably falls on one side of the border" [14]. However, at the same time, he is a person "prepared to straddle a no-man's-land" [14], in order that a convergence and meeting might become possible in a common area. It appears, then, that while there is a border, there is also the strong possibility of finding a meeting point, a middle space at the threshold, if only one undertakes the (discursive and existential) work necessary to attain this.

Using an architectural metaphor, Moosa [14] conceives the location of that threshold as having entrances, doors, and being surrounded by rooms (see Figure 1). In Moosa's words:

\section{it is the critical intermediate space between outside and inside, between exoteric (zāhir) and esoteric (bātin). It is also the space that one has to traverse in order to enter or exit, which is the real function of a threshold area. (ibid., p. 48)}

Furthermore, one of the main purposes of that space is to allow the house residents to see from inside to outside properly, while preventing the people outside from seeing into the inside of the house easily and directly. 


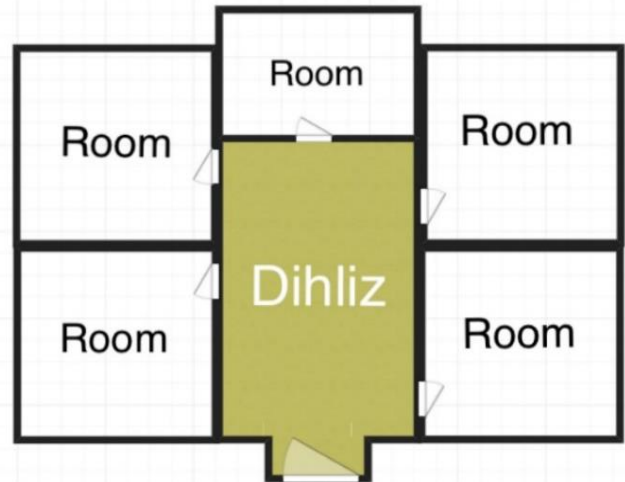

Figure 1. Showing the Location of "Dihlīz"

Another function of the dihliz is that it is a space in which people who come in from outside can be received by the residents and given a warm welcome [14]. In this case, the threshold is not "a border that serves as a territorial demarcation between sovereign territories and criminalizes improper crossing" [14]. At the same time, it is a space in which authorization can be sought to access appropriately with high tact and in a disciplined manner, the people living in the house or passing in the street. It is also a space which can be both private for the residents and public for strangers, as well "fram[ing] all other spaces" [14].

For the purpose of this section, it can be said that the concept of "dihlīz" has become "a new locus of epistemic and political enunciation" [14]. According to Moosa, the concept of dihlizz, based on al-Ghazali's thought, can be summarised in three points: a space for starting and finishing ideas; a locus of the enunciation and creation of texts; and a place of drawing up the standards of the liminal. Moreover, "it lends itself to non-totalitarian modes of being and thought." [14].

Through the previous discussion, whilst Moosa [14] notes that the dihlìz is itself a spatial metaphor, deriving from the vestibule for entrance to a building, it does not, as mobilized within Ghazali's philosophy, engage the socio-material dimensions of learning. For these dimensions of change it is necessary to look elsewhere, to more recent writings within socio-material traditions of thinking that engage the empirical with the philosophical. AlGhazali here may represent the empirical side in which he was an example of how to engage in dialogues within the specific traditions at that time (see Figure 2).

From studying al-Ghazali's thought, it appears that there are three main axes:

1. Defining and drawing the boundaries of the dialogue which respect the constants and fundamentals as well as the branches and issues of debate;

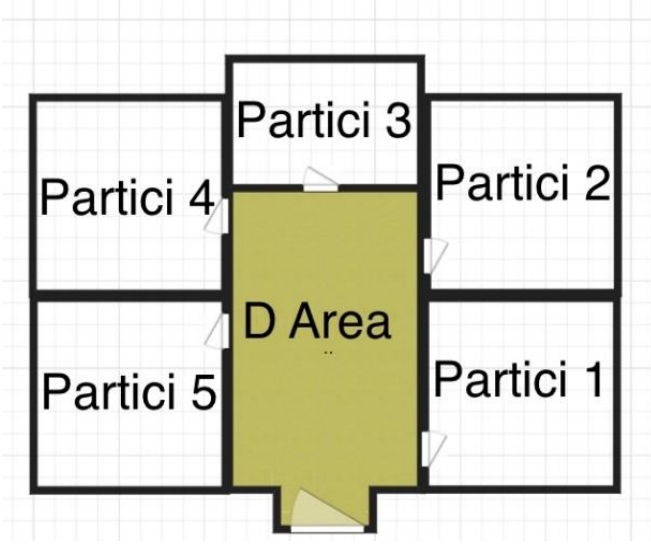

Figure 2. "Dihlīz" and Dialogue

2. Moderation, or the middle between different opinions, like the dihlizz, which is in the middle space of the entrance of the house;

3. The ethics and morals involved in dealing with entry and exit, and, on the other side, facilitating contact between those who are outside of the house and the residents or between the residents and the people outside.

Thus, these three points: borders, moderation and morality, may be reflected in an approach to dialogical thinking and be considered as the criteria for successful interaction in dialogical activities in Islam.

\section{Dialogue Thinking in Islam}

Dialogical interactions between people are framed by different traditions operating within the cultural contexts which the dialogue embraces. This can explain why the culture of dialogue can be understood differently from one society to another. The main question here is how is 'tradition' to be understood in Muslim and Arab culture? In Arabic, there is no exact equivalent translation of the term 'tradition' itself. The nearest equivalent is religion $(d \bar{i} n)$, paralleling the western category of 'religion' [14], which can bring with it very conservative understandings of creed. Thus, appeals to 'tradition', within some Islamic contexts, might unwittingly align discourse with approaches that severely limit dialogical possibilities.

In Saudi Arabia, the community is, in many respects, a 'mono-cultural society', in which the whole population follows the same Islamic religion, uses one language, has one government and one religious institution. At the same time, the country has had a prominent role in international affairs from the establishment of the first Saudi state in 1744 up to the present, where it is well known as an Islamic and Arabic state [17]. Moreover, the location of the country is where the revelation was sent down to the 
Muslims' messenger, Muhammad (PBUH), and the location of the two most holy mosques for all Muslims throughout the world. Thus, dialogue, in a country like Saudi Arabia, is framed by the religion of Islam; the fabric of Saudi society is inextricably linked to the rules of Islam and its citizens are likely to be accepting of those rules, and more satisfied about its sources: the Qur'an and Sunnah. These considerations may lead us to understand that the culture of dialogue in this context will be somewhat different from that in many other countries.

Dialogue, for Muslims, concentrates on innate dispositions, social interactions, interfaith connections, and respect for diversity. In Islam, one of the goals of engaging in dialogue is simply to help resolve conflicts between groups, but this is not its only goal. Dialogue is a major part of Islamic culture, so Muslims look upon dialogue as a human interaction, one of the natural habits of everyday life. Thus, interaction is required between different groups, whether the groups are similar or different in faiths and ideologies, in order to improve relationships among people [11.

Asad [3] draws attention to some of the defining features of discursive traditions that come under the umbrella of Islam. A critical factor informing all such conversations is the foundational importance attached, as we have seen, to both the Qu'ran and Sunnah (Sayings of the Prophet (PBUH)). Thus, it is important to first look at how these texts have been interpreted by scholars in relation to dialogical principles and practice.

Qur'an verses and Sunnah statements support a number of the principles identified above in relation to dialogue. For example, in the Qur'an, God (Allah) the Exalted says:

\{O mankind, indeed. We have created you from male and female and made you peoples and tribes that you may know one another. Indeed, the most noble of you in the sight of God is the most righteous of you. Indeed, God is Knowing and Acquainted.\} (49:13)

This verse is a kind of invitation to all people of the world to be united. This can be detected through the phrase "know one another" and has been explained by Altwaijri [2] who said that the meaning of "know one another" (acquaintance) in this verse will extend to include cooperation, conjunction, coexistence, and all forms of positive joint humanitarian work, which is the greatest objective of dialogue.

In the Qur'an, also, Allah the Exalted says:

\{Say, "O People of the Scripture, come to a word that is equitable between us and you that we will not worship except God and not associate anything with Him and not take one another as lords instead of God.\} (3: 63)

This is another invitation from the Qur'an, albeit a slightly different one. In the previous verse, the invitation was for all people to be closer to each other and to be more acquainted with and connected to one another generally. However, in this verse the invitation is for Muslims to open channels of dialogue with people of the Scripture, and in all Qur'anic interpretation [2], the people of the Scripture are the Jews and Christians. Thus, it is a kind of motivation for Muslims to have good relationships and dialogue, as well as to be open to people from other religions, while keeping their Muslim identity and their beliefs. In the Qur'an, Allah the Exalted says:

\section{$\{$ But if they turn away, then say, "Bear witness that we are Muslims [submitting to Him].\} (3: 63)}

From those verses, it would seem that Islam calls upon Muslims to engage and communicate with the larger global community, with the religious community at the second level, and, consequently and naturally, within the small community that follows the same religion, which is Islam. At the same time, as mentioned in the previous verses, Islam has framed those calls to engagement, openness, and dialogue with no separation between Muslims, their ideologies, faith and culture. That may explain why Islamic dialogue is surrounded by certain boundaries and restrictions.

In Islam, many points need to be considered for dialogical activity to achieve its objectives, and it is essential for these points to be known and respected by interlocutors. As Bawazeer [6] emphasises, these are 'assets' that comprise the principles and rules that control the interlocutors and inform the operation of a given dialogue. Furthermore, they assist listeners and beneficiaries engaging in a dialogue in making decisions regarding the closeness of these interlocutors to the correct way of thinking, depending on religion, culture, and ethics. When these assets are not respected, the dialogue will have no benefit and will not achieve the desired outcome, subsequently leading to controversy, which is the inverse of successful dialogue. Hence, it is important to identify some of the assets of dialogue in Islamic culture.

Comparing this with Al-Ghazali's thoughts on dialogical thinking, it can be noted that there are some boundaries that need to be taken into account when undertaking dialogic activities in Islam. There are two essential principles for a successful dialogue in Islamic culture: respect for the constants of Islam and observance of Islamic ethics, in general, and dialogic ethics in particular. These two principles are 
similar, to some extent, to those main axioms detected by Moosa [14] in the concept of 'dihlīz' in Al-Ghazali's thought.

In terms of respecting the constants of Islam in dialogue, it is necessary to consider religious constants and the principles of the Islamic faith, which might, in this instance, render some topics as inappropriate for discussion. If that happens, it is thought that the discussion will help turn dialogue into conflict and the resulting debate will be sterile [18]. The greatest constant for all Muslims and in Islamic faith is God (Allah). In this constant, all believers in Islam must believe in God (Allah), He is the only one, and there is no God except He. In this case, "when the pronoun "He" is used to refer to God, of course it carries no gender connotations. God is beyond such classification and the question is one of linguistic usage which is both limited and arbitrary" [10].

And when reference is made to God (Allah), there is no doubt that God (Allah) is one God for all, Jews, Christian, and Muslims. MacIntyre [13] has interpreted who is the God in the scripture:

what scripture says about God is to be interpreted as well as understanding the conclusions of those sciences. About God we know that he is and what he is not. We know that he is because he revealed himself to the prophets and especially to Moses and because we have a proof that God exists, that he is one, and that he is not a body. The God whose existence is demonstrated is the prime mover of the physical universe as described by Aristotle. Yet, although we know that God exists, we can form no conception of his attributes. It is not just that our conception of them is inadequate, but that the very nature of God, rightly understood, is incompatible with his having attributes. So that whenever we do ascribe attributes to God-and we are authorized by biblical revelation to use certain attributive expressions in speaking of God-we are to understand what we say only as a set of denials, denials that God is limited in the way that we are limited, in respect of his power, goodness, knowledge, and the like.

In Islam, the interpretation of God (Allah) is not at all different to what has been interpreted in the scripture. Hathout [10], replying to atheists' argument about God (Allah), explains that He is the creator of all of the creations in the universes:

If He is the Ultimate Creator, it follows that nothing could be "more" than Him in any respect, or else He would be "less" than something, He would have limits, and this would be incompatible with being the
Ultimate One or the Primary Cause that philosophy refers to. His dimensions in all His attributes can be expressed in terms of infinity. Of course, we cannot comprehend what infinity really means, but we should acknowledge that this is only natural since we are finite, and the finite cannot comprehend the infinite ... God is therefore infinite. He therefore can comprehend us although we, by our finitude, cannot comprehend Him, and we know about Him by knowing His signs and manifestations through His creation. And since infinity cannot be divided by two or three or more ( $a$ mathematical fact), it follows that there cannot be God for Jews, another for Christians, another for Muslims, another for Hindus and yet another for the Godless, etc. God is One! It is this Oneness of God that is at the root of the Islamic faith and the belief of Muslims.

Thus, in MacIntyre [13] and Hathout's [10] accounts, God is one and has no body, His great attributes are infinite and unlimited and cannot be known except through clear and explicit revelation to the prophets: Moses, Jesus, and Muhammad and other prophets (peace be upon all of them). It is also clear that there are two important things about God (Allah): His attributes can be described only by revelation, and the details of belief, legislation, and religion are conveyed to us by prophecy and through revelation. However, any discussion about God (Allah) without any clear and explicit evidence from the Qur'an or Sunnah (revelation) could lead to disagreement and conflicts, which may explain why conflicts exist between people, especially between Muslims, when they have to discuss that point. Lemcio and Williams [12] describe the case of Ahmad ibn Hanbal who was punished for his resistance to the radical movements which sought to undermine the authority of the Qur'an and how the discussion about constants can lead to disagreement and dissension:

"Such groups of conservative thinkers often looked back to the ninth century scholar Ahmad ibn Hanbal (d. 855), whose resistance to more radical developments had earned him a whipping and imprisonment. The main group opposing him [...] championed the use of reason in interpreting the Qur'an and drawing out the possibilities implicit in its teachings. Thus, with regard to the anthropomorphisms, such as God's hand being outstretched or his being seated on his throne, they insisted that these could not be taken literally because they risked similarity between God and human beings and must 
therefore be interpreted metaphorically: God's "hand" was his grace, and his "being seated" on his throne denoted his supreme power. More than this, they inferred from their definition of the absolute oneness of God that the Qur'an could not be eternal because it would then be a second eternal entity alongside God. This made the scripture less of an absolute authority for theological minds to contend with or for rulers to have to obey. In fact, the caliph of the day made it official policy that anyone seeking public office must affirm the createdness of the Qur'an. It was Ibn Hanbal's disagreement with this principle that earned him his punishments".

It is really important to provide this story here. It shows how dialogue can become sedition and lead to division within the society. In fact, any verses in the Qur'an about God (Allah) should not be interpreted through speculation but by reference to the Qur'an itself or the Sunnah. Thus, Hathout asserts that the Qur'an and Sunnah are the main sources of the Shari'a in Islam, saying: "the Qur'an deals with a full range of issues ranging from the establishment of the creed ... The Sunna sometimes explains the Qur'an, illustrates it, details some generalities and complements it in some areas" [10].

Consequently, it is not allowed for anyone to interpret any verse of the Qur'an or the Sunnah about the creed, especially regarding God (Allah) or divulging anything about God (Allah), except that which is mentioned clearly and directly in both the Qur'an and Sunnah, "because this is something beyond the ability of ordinary people, and it could lead them into confusion and dispute" [12]. Moreover, the engagement of the participants in dialogue with regard to creed, without sufficient knowledge of the Qur'an and Sunnah, will lead to a situation in which:

\section{[The people's] complaints and doubts will multiply, making it difficult for a human to control them. For it is not for everyone that [the acquisition] of divine wisdom is facilitated [4].}

This kind of multiplication of doubts and intellectual activity can create divisions between the interlocutors and the Muslim community. This division could lead to the establishment of extremist groups, one group on the far right side on dealing with opinions and the second group on the far left, and here, ethics will be the other essential principle, besides respect for the constants of Islam.

The topic of moderation in dialogue is one of the most active areas of ethics and morality in Islam. In the Qur'an, God (Allah) the Exalted confirmed that the Muslim Nation is a moderate nation:

\section{\{And thus We have made you a median community.\} (2: 143)}

In this verse, Allah the Exalted explains that the Islamic nation is a nation of moderation. Religious scholars who study the Qur'an have suggested several interpretations of the words "median community". Hanapi [9] summarises these interpretations as follows:

\section{It is clear that the term wasata (the middle between two extremes) means the chosen, the best, being fair, humble, moderate, istiqamah (to go straight into the right direction, acting rightly, allowing no deviation), follow the teachings of Islam, not extreme to either end in matters pertaining worldly or the after-life, spiritual or corporeal but should be balanced between the two ends [9].}

In other words, in dialogue, what is essential is not to be at one end and reject the other, but rather, to be in the middle between two opinions. MacIntyre [13] and Hanapi [9] describe this location as "a norm between two extremes" (p. 56), or "a position between two extremes" (p. 54). Islam is not the only religion to emphasise moderation. MacIntyre [13] makes a connection between moderation and virtue as a path on which people can walk in the middle between two extremes:

\begin{abstract}
In general ben Maimon follows Aristotle in conceiving of a moral virtue as a norm between two extremes, as, for example, liberality is the mean between extravagance and stinginess, and courage the mean between rashness and cowardliness. Aristotle had nonetheless emphasized that with regard to some traits we are required to move toward one extreme and away from the other, and ben Maimon makes the same point, especially with regard to the putting off of pride and the cultivation of humility.
\end{abstract}

Thus, moderation, in Islam, is not just an ethical principle but can be a producer of virtues. Moderation can help instill noble values such as honesty, loyalty, generosity, kindness, leniency, compassion, justice and equity. Moderation also means treating people kindly, recognising the rights of others, whether or not they are of the same religion, race, sect or ancestry [9], and having a high standard of behaviour which is reflected in the most appropriate words and acts. Being moderate should not be limited to attitudes when amongst Muslims or to those with whom there is philosophical, cultural 
and intellectual agreement. Rather, it should be the basis of a Muslim's dealings with all people, as by treating them kindly we are following God (Allah) the Exalted's commandment to do good, as stated in the Qur'an:

\{O you who have believed, be persistently standing firm for God, witnesses in justice, and do not let the hatred of a people prevent you from being just. Be just; that is nearer to righteousness. And fear God; indeed, God is Acquainted with what you do.\} (5: 8)

Thus, morality and virtue are the main results of moderation in dialogical thinking, as explained by Moosa [14], in connection with al-Ghazali's thought and the concept of 'dihliz', as well as by MacIntyre [13]. Mubarak [15] cites al-Ghazali's emphasis on the morality principle in his book of Minhaj al'abidin (The way of worshippers), where morality is stated as the right path to be closer to God (Allah). Mubarak provides an in-depth analysis of the morality of al-Ghazali, explaining that al-Ghazali emphasises that all human beings need to acquire the potential virtues that can be transformed into good behaviour. Al-Ghazali describes the best way to achieve this, which is for people to learn how to diagnose the behaviours and distinguish between the virtues and the vices, as well as practising the good behaviours so that they become habits [15]. Therefore, based on the above discussions, it can be recognised that moderation is a core concept of Islam. Moderation, virtue, morality and behaviour are an integrated and comprehensive approach to reform the individual and to solve all the Muslim community's demands and problems, which, in turn, influence dialogical activities both directly and indirectly. All this suggests that there is an important place for the practice of Islam "in a balanced and comprehensive manner in all aspects of life and society by focusing on improving the quality of human life [9].

The education system can be regarded as an appropriate field for educating the population in how to achieve balance in their lives, and how to engage in the operation of dialogue and dialogical activities, bearing in mind their culture and tradition. Balance is a concept that seeks to develop people's consciousness, not individually but by interaction with others within the society. As Bakhtin [5] argues, exchanging different perspectives, in dialogue and interaction between people, can lead to the development of consciousness, whether individually or collectively.

In Muslim society the discursive tradition depends on the Qur'an and the Sunnah (Hadiths) [3]. These sources, which are composed of a creed, morals, virtues, and values, are considered as a coherent frame for the religion of Islam. On the other hand, differences in time and place require changes in the discursive tradition and releasing the traditions from restrictions that are judged to be unnecessary. This change might create a space for a debate between conservative voices who claim to adhere to the founding texts of the Qur'an and Sunnah, and other voices who want to deal with these texts free from any restrictions. This could, of course, cause conflict and dissension, which may then require the presence of religious dialogue between members of the Muslim community to reduce the resulting gap.

Al-Ghazali is a good example of a scholar who adheres well to the Qur'an and Sunnah and at the same time participated in a great debate with Ibn Rushd and others. Moosa [14] explains al-Ghazali's thought and how al-Ghazali engaged in a process of posing questions and seeking answers, a process which ultimately led to his openness to other thinkers and to those who held of different views. As explained above, the concept of 'dihlīz' as the main door and vestibule of the house which links the outside and the many doors inside, captures and distils a key facet in al-Ghazali's thinking [14]. So, while al-Ghazali followed and was restricted by the Qur'an and Sunnah, he was also open to other thinkers who surrounded him at that time. These restrictions are, firstly, respect for the constants of religion and creed, especially with regard to God (Allah), the body of God (Allah), and His attributes, as well as the Prophet Muhammad (PBUH) and the revelation that descended upon him. The other restriction to take into account is maintaining moderation and ethics, which help individuals to act justly, and honestly, guiding them to the right behaviours in a balanced way.

The more important question here is about the possibility of converting this conceptual theoretical framework into real educational practices in religious education in the context of universities in Saudi Arabia. Currently, the problem is that university curricula are generally based on just one textbook for each course and do not involve dialogue; this is particularly true of religious education. A re-think within Saudi university education may be required that involves inserting some dialogical activities which, whilst taking into account Islamic tradition, Saudi culture and Islamic fundamentals and constants, are at the same time open to other cultures. Therefore, this study aimed to find the possibilities of practising dialogue within the University's classrooms in religious education courses, based on the different theories of the dialogue and an understanding of the Saudi traditions.

\section{Methodology}

The qualitative research serves several purposes in the present project; for example, it allows testing, theory generation, the creation of key concepts, 
description and reporting [8]. Since this study aimed to investigate the case of the culture of dialogue in a specific community (a specific Saudi university, and a particular course), a qualitative and instrumental type of case study was used. One of the features of such case study research is that it reports its relationship with "the real-life, complex dynamic and unfolding interaction of events, human relationships and other factors in a unique instance" [8].

Following the suggestions of Cohen et al. [8] that the minimum essential methods for data collection in qualitative case study should include semi-structured interviews (individual and group), observation, and documentary research, the methods of collecting data in this study were:

a) semi-structured interviews with male and female teachers and students who were teaching and attend the religious education modules in the university where the case study was based. These interviews with academic teachers and students aimed to understand the culture of dialogue in the university environment, and in its classrooms in particular.

b) open observation in the classrooms of the religious education modules: while doing this I also engaged with teachers and students in the lessons by asking questions and introducing relevant points for discussion.

c) analysis of a number of documents touching upon the issue of dialogue in general in Saudi Arabia.

This research took place in one of the Saudi universities, where a case study could be conducted.

\section{Main Findings}

This study focused on the possibilities of practising dialogue within the University's classrooms in religious education courses, based on the different theories of the dialogue and an understanding of the Saudi traditions. The study found a range of understandings of the concept of dialogue among Saudi officials, academics teachers, and students. One of the significant findings to emerge from this research is that dialogue in Islamic tradition is framed by three major elements which must be respected during any dialogical activities: moderation, virtue, and dialogue with others.

In terms of the boundaries of dialogic activities, respondents shared the view that the Exalted God (Allah), Prophet Mohammad (PBUH), revelation, the texts of Qur'an, and the texts of Sunnah are foundations sacred in Islam and are highly respected and, therefore, dialogue about those sacred aspects is unacceptable in the Islamic tradition. However, the findings also show that dialogue in the Islamic tradition is accepted within the context of legislation (Fiqh) and in relation to contemporary issues. All respondents were in strong agreement about this.

As illustrated above, through a consideration of the writings of al-Ghazali from within the Islamic discursive tradition moderation, virtue and acceptance of differences are key pillars in a distinctively Islamic approach to dialogue. The analysis of the interviews and documents showed that the combination of these virtues is also regarded as an integral component of dialogue in Saudi society, and are in full agreement with the tenets of Islam in this aspect, which seeks to promote dialogue within the society by education or by the activities of the King Abdulaziz Centre for National Dialogue. On the other hand, through comparing the findings to theoretical understandings of dialogue, extremism was seen to be an outcome of monologue, the single thought, adhering to the opinion and the selfconsciousness which prevents dialogue from achieving a middle point between two views. Respect for difference as a core value of dialogue is required in any interaction that aspires to be dialogic, and awareness of the importance of moderation and virtue is more likely to foster respect for differences within dialogue.

The third element is respecting others, which is clearly supported by dialogue in the Islamic tradition. While the Islamic tradition invites Muslims to deal with those from different cultures with respect, the findings from this research suggest that the concept of respect for others is not fully embedded within the community. Interestingly, findings show that Saudi people have a rather narrow understanding of the 'other', as non-Muslim. Moreover, such respect does not necessarily extend to the opinions of others. Therefore, when discussing the principle of respect for others, it needs to be made clear that this is a comprehensive term which includes Muslim or non-Muslim, Saudi or nonSaudi, male or female, from same tribe or other tribes, and from the same culture or different cultures - and extends to respecting others' opinions.

The research revealed a fourth element to add to the previously discussed Islamic principles that constitute the dialogic frame, which is the notion of national unity in the Saudi context, something that was emphasised by all the participants interviewed for this study. They saw conflicts, disagreements, and violence as impacting negatively on that unity. Moreover, it emerged that respondents appeared not to be interested in political issues, had little to share about politics and avoided this subject in general since they thought that any conversation about politics would lead to conflict and disunity. Thus, one of the more significant findings of this study is the identification of this fourth element within the frame of dialogue in the Saudi community, which pertains to the maintenance of national unity alongside respect for the Saudi monarchical system.

Moreover, students identified three main factors that discouraged them from engaging in dialogue: psychological factors such as fear and lack of confidence; lack of practical experience in engaging 
in dialogue within the classroom; and lack of knowledge. When teachers seek to promote a culture of dialogue, these three factors should be taken into account. The core role of the teacher in this regard is promoting and motivating students to get involved in dialogue, creating opportunities for students to speak freely and providing a safe environment in which students can express their opinions. Moreover, teachers need to use teaching methods that will increase student motivation and create an atmosphere of active learning, self-learning, and knowledge exchange, instead of the traditional teaching methods focused upon alignment with and memorization of a pre-established text, which was heavily criticised by all participants.

If the university administration is committed to working towards providing an appropriate learning environment, especially if it wants to keep pace with national projects in general and to play an active role in supporting the dialogue project, the university should concentrate on the performance of its teachers by providing a training programme specific to academic teaching. The study shows that some teachers are enthusiastic about their subject but lack the skills to teach effectively. In addition, both university management and academic departments need to recognise the importance of including appropriate academic activities within the university towards the development of students' overall abilities and dialogical capacities. Thus, they have the responsibility to design seminars and group discussions on a variety of social and educational issues.

\section{Conclusion}

This paper has focused on the thinking of alGhazali as an exemplar of dialogical practice within the Islamic tradition, whose work testifies to the possibility of combining a tradition-centred approach with more open dialogical practice. In his case, such an openness to difference was combined with both a respect for the Qu'ran and Sunna, and other Islamic foundational texts, and was deeply rooted in the practice of his tradition.

The most appropriate educational environment in which to apply the Islamic theory of dialogue is that of the university. This study has highlighted the importance of dialogue in the educational system generally and in religious education in particular from both theoretical and empirical perspectives. This involves implementing an appropriate understanding of dialogue in religious education in Saudi universities.

This paper has shown the importance of dialogue in education and the multiple points of view on its theory and practices. Returning to al-Ghazali's underlying metaphor of dihlīz (the entry threshold and vestibule of the house of learning and religion), I have attempted to interpret and highlight the impediments and obstacles to dialogue in education and the wider community. In addition, I have made practical suggestions in terms of how the university's administration, teachers, students, and writers of religious education textbooks can improve their own space for professional action and, through this, provide opportunities for practising dialogue within the religious education classrooms based on the frame of the thought of Al-Ghazali and an understanding of the concepts of dialogue in Islam.

\section{References}

[1] Al-Shami, S., Imam al-Ghazali. Beirut: Darul Qalam, 1993.

[2] Altwaijri, A., Dialogue for Coexistence. Cairo: Dar Al Shorouk, 1999.

[3] Asad, T., The Idea of an Anthropology of Islam. Occasional Paper Series. Washington, D.C.: Center for Contemporary Arab Studies, Georgetown University, 1986.

[4] Avicenna, The Physics of the Healing. Provo, Utah: Brigham Young University Press, 2009.

[5] Bakhtin, M., Problems of Dostoevsky's Poetics. Minneapolis: Theory and History of Literature, Vol. 8., University of Minnesota Press, 1984.

[6] Bawazeer, A., The Role of an Islamic Education Teacher in Developing Secondary Students' National Dialogue Abilities. Riyadh: King Abdulaziz Centre for National Dialogue, 2010.

[7] Bowker, J., The Religious Imagination and the Sense of God. Oxford: Clarendon, 1978.

[8] Cohen, L., Manion, L and Morrison, K., Research Methods in Education. Oxon: Routledge, 2011.

[9] Hanapi, M., The Wasatiyyah (Moderation) Concept in Islamic Epistemology: A Case Study of its Implementation in Malaysia. International Journal of Humanities and Social Science, Volume. 4, Issue 9 (1), 2014, p. 51-62.

[10] Hathout, H., Reading the Muslim Mind. USA: American Trust Publications, 1995.

[11] Kurucan, A. and Erol, M, Dialogue in Islam: Qur'an - Sunnah - History. London: Dialogue Society, 2012.

[12] Lemcio, E. and Williams, R., A Man of Many Parts: Essays in Honour of John Bowker on the Occasion of His Eightieth Birthday. Eugene, Oregon: Pickwick Publication, 2015.

[13] MacIntyre, A., God, Philosophy, Universities: A Selective History of the Catholic Philosophical Tradition. Lanham, MD: Rowman \& Littlefield, 2009.

[14] Moosa, E., Ghazālì And The Poetics Of Imagination. North Carolina: University of North Carolina Press, 2005.

[15] Mubarak, Z., Morality of al-Ghazali. Cairo: Kalimat Arabia, 2012.

[16] The Qur'an, The Qur'an: With Surah Introductions and Appendices (English Translation: Saheeh International Translation). Birmingham: Maktabah Booksellers and Publishers, 2013.

[17] Wagemakers, J., Kanie, M. and Geel, A., Saudi Arabia Between Conservatism, Accommodation and 
International Journal of Technology and Inclusive Education (IJTIE), Volume 9, Issue 2, 2020

Reform. Clingendael: Netherlands Institute of International Relations, 2012.

[18] Zamzami, Y., Morals and Permissions of Dialogue in Quran and Sunah. Amman: Dar Al-Maali, 2002. 